\title{
Preservation Property and Decay Kinetic of Polyurethane Immobilized Nitrifying Bacteria Pellets
}

\author{
Yamei Dong \\ Technology Center, Shanghai Institute of Mechanical \& Electrical Engineering CO., LTD, Shanghai, China \\ Email: ymdong515@163.com
}

How to cite this paper: Dong, Y.M. (2018) Preservation Property and Decay Kinetic of Polyurethane Immobilized Nitrifying Bacteria Pellets. Journal of Geoscience and Environment Protection, 6, 93-100. https://doi.org/10.4236/gep.2018.66007

Received: March 30, 2018

Accepted: June 19, 2018

Published: June 22, 2018

Copyright $\odot 2018$ by author and Scientific Research Publishing Inc. This work is licensed under the Creative Commons Attribution International License (CC BY 4.0).

http://creativecommons.org/licenses/by/4.0/

\begin{abstract}
The preservation methods of polyurethane immobilized nitrifying bacteria pellets which had been enriched in laboratory were provided. Factors such as temperature, $\mathrm{pH}$ and light, which affect the nitrification activity of polyurethane immobilized pellets, were investigated. The result showed that dark, deionized water and low temperature is suitable for polyurethane immobilized nitrifying bacteria pellets' long term preservation.
\end{abstract}

\section{Keywords}

Immobilized Nitrifying Bacteria Pellets, Relative Activity, Decay Kinetic, Preservation Methods

\section{Introduction}

The ammonia degradation and preservation ability of nitrifying bacteria products were two important factors affecting its commercialization [1] [2]. The previous researchers have confirmed the polyurethane immobilized nitrifying bacteria pellets have a higher nitrification activity [3] [4]. How to effectively keep the high activity of nitrifying bacteria pellets for long-term storage is an urgent problem in its technology application [5] [6]. Because active decay of nitrifying bacteria in the preservation process is complex, it depends on lots of environmental factors [7]. Few studies on the decline of nitrifying bacteria and the research of immobilized nitrifying bacteria products preservation process have not been reported [8] [9]. This study examined the light, temperature, $\mathrm{pH}$, and other major factors, which affect preservation activity of immobilized nitrifying bacteria pellets, to find out the best preservation methods. This study will optimize 
the preservation and transportation conditions of immobilized nitrifying bacteria pellets.

\section{Materials and Methods}

\subsection{Preparation of Nitrifying Bacteria Pellets}

Activated sludge was obtained from the aeration tank of Minhang municipal wastewater treatment plant, Shanghai, which was utilized as seed sludge for acclimating nitrifying bacteria and acclimated in laboratory for 2 months. The suspensions of nitrifying bacteria were concentrated to the density of $20 \mathrm{~g} / \mathrm{L}$ and mixed with a polyurethane prepolymer emulsion. Then N, N, N',

$\mathrm{N}$-tetramethylenediamine as a promoter and potassium persulfate as initiator were added to the beaker. Consequently; the polyurethane immobilized nitrifying bacteria in the form of an elastic gel were obtained. The resulting polymerized gel carrier was cut into $3 \times 3 \times 3 \mathrm{~mm}$ cubes by the special cutting machine and then washed thoroughly with distilled water [10].

\subsection{Relative Activity of Nitrifying Bacteria Pellets}

Nitrifying bacteria are oxygen-consuming bacteria. The change of nitrifying bacteria pellets activity during the preservation process was measured by oxygen uptake rate. The respiration rate was obtained by measuring the oxygen uptake of pellets with a dissolved oxygen meter at $25^{\circ} \mathrm{C}$. The change of nitrifying bacteria particles activity in the preservation process was tested using the following method. Inorganic synthetic wastewater saturated with oxygen was placed in a $100 \mathrm{~mL}$ incubation flask along with $20 \mathrm{~mL}$ of pellets. They were then stirred. The respiration rate was obtained by measuring the decrease in dissolved oxygen concentration. The relative activity of preservation pellets was calculated by Equation (1).

$$
R_{r}=\left(R_{1} / R_{0}\right) \times 100
$$

where $R_{r}$ is relative activity (\%), $R_{1}$ is the respiration rate of pellets preservated for a certain time (mg- $\mathrm{O}_{2} / \mathrm{L}$-pellet-h) and $R_{0}$ is the respiration rate of the pellets before preservation $\left(\mathrm{mg}-\mathrm{O}_{2} / \mathrm{L}\right.$-pellet-h).

\subsection{Calculation and Model Fitting}

After determination of polyurethane immobilized nitrifying bacteria pellets' respiratory activity interval a certain time, the decay rate $\left(K_{m}\right)$ and half-life $\left(t_{1 / 2}\right)$ fitting model was calculated according to Equation (2).

$$
R_{r}=\exp \left(-K_{m} \times t\right) .
$$

where $R_{r}$ is relative activity (\%), $K_{m}$ is the decay rate $\left(\right.$ day $\left.^{-1}\right)$ and $\mathrm{t}$ is the preservation time (day). 


\section{Results}

\subsection{Effects of Light on the Preservation Activity of Nitrifying Bacteria Pellets}

Light have a negative impact on the nitrifying bacteria [11]. Experimental results of effects of light on pellets activity are shown in Figure 1(a). As shown in Figure 1 , the decay rate $\left(K_{m}\right)$ and half-life $\left(t_{1 / 2}\right)$ of particles preservation in the light place were $0.0464 \mathrm{day}^{-1}$ and 15 days, and the values were $0.0123 \mathrm{day}^{-1}$ and 56 days under dark condition, respectively. The half-life in dark was almost two times longer than it in light conditions, but still less than 2 months. Therefore, the method of room temperature away from light is only suitable for short-term preservation of nitrifying bacteria pellets.

\subsection{Effects of pH Values on the Preservation Activity of Nitrifying Bacteria Pellets}

Nitrifying bacteria on is very sensitive to the changes of environmental $\mathrm{pH}$ value. Bacteria grows well in slightly alkaline environment [11]. The optimum pH range of nitrification bacteria was 7.0 - 8.5 [12]. Preservation activity of nitrifying bacteria pellets under different $\mathrm{pH}$ values were determined, and fitted according to equation (2). The experimental results of the decay rate $\left(K_{m}\right)$ and half-life $\left(t_{1 / 2}\right)$ are shown in Figure $1(b)$. Under alkaline conditions was better for pellets preservation, half-life of almost 50 days when $\mathrm{pH}$ of 7.5. But pellets' activity half-life was 56 day when they stored in deionized water. Analyze the reasons may be that phosphate buffer added to improve the system in the ionic strength have an adverse effect on the activity of nitrifying bacteria pellets. As can be seen from the above results, particles can maintain activity better in deionized water for preservation.

\subsection{Effects of Temperature on the Preservation Activity of Nitrifying Bacteria Pellets}

Temperature has a greater impact on the growth and preservation of nitrifying bacteria. Generally believed that the suitable temperature range of nitrifying bacteria growth of $20^{\circ} \mathrm{C}-30^{\circ} \mathrm{C}$ [13] [14] [15].The respiratory activity of nitrifying bacteria particles, which were placed in different temperature $\left(4^{\circ} \mathrm{C}, 20^{\circ} \mathrm{C}\right.$, $30^{\circ} \mathrm{C}, 35^{\circ} \mathrm{C}$ and $40^{\circ} \mathrm{C}$ ) were determined and calculated according to equation (2) fitting model. The results of the decay rate $\left(\mathrm{K}_{\mathrm{m}}\right)$ and half-life $\left(\mathrm{t}_{1 / 2}\right)$ are shown in the Figure $1(\mathrm{c})$. At $4^{\circ} \mathrm{C}, 20^{\circ} \mathrm{C}, 30^{\circ} \mathrm{C}, 35^{\circ} \mathrm{C}$ and $40^{\circ} \mathrm{C}$ condition, nitrifies particles activity of $4^{\circ} \mathrm{C}$ decayed slowest. With increasing temperature, the decay rate was accelerated from 0.0056 day $^{-1}$ to 0.0333 day $^{-1}$ and half-life was shorted from 124 days to 12 days of $4^{\circ} \mathrm{C}$ to $30^{\circ} \mathrm{C}$. This also showed that the lower temperature was better for keeping preservation activity of nitrifying bacteria particles. In summary, the preservation at $4^{\circ} \mathrm{C}$ temperature conditions, the nitrifying bacteria particles can achieve longer time (3 - 6 months) storage. 


\subsection{Effects of Freeze on the Preservation Activity of Nitrifying Bacteria Pellets}

In order to extend the preservation time of polyurethane immobilized nitrifying bacteria pellets as long as possible, the storage temperature was further reduced below $0^{\circ} \mathrm{C}$ to $-20^{\circ} \mathrm{C}$. The experimental sample particles divided into two parts, which half were directly frozen, the other half added $10 \%(w / w)$ glycerol as a

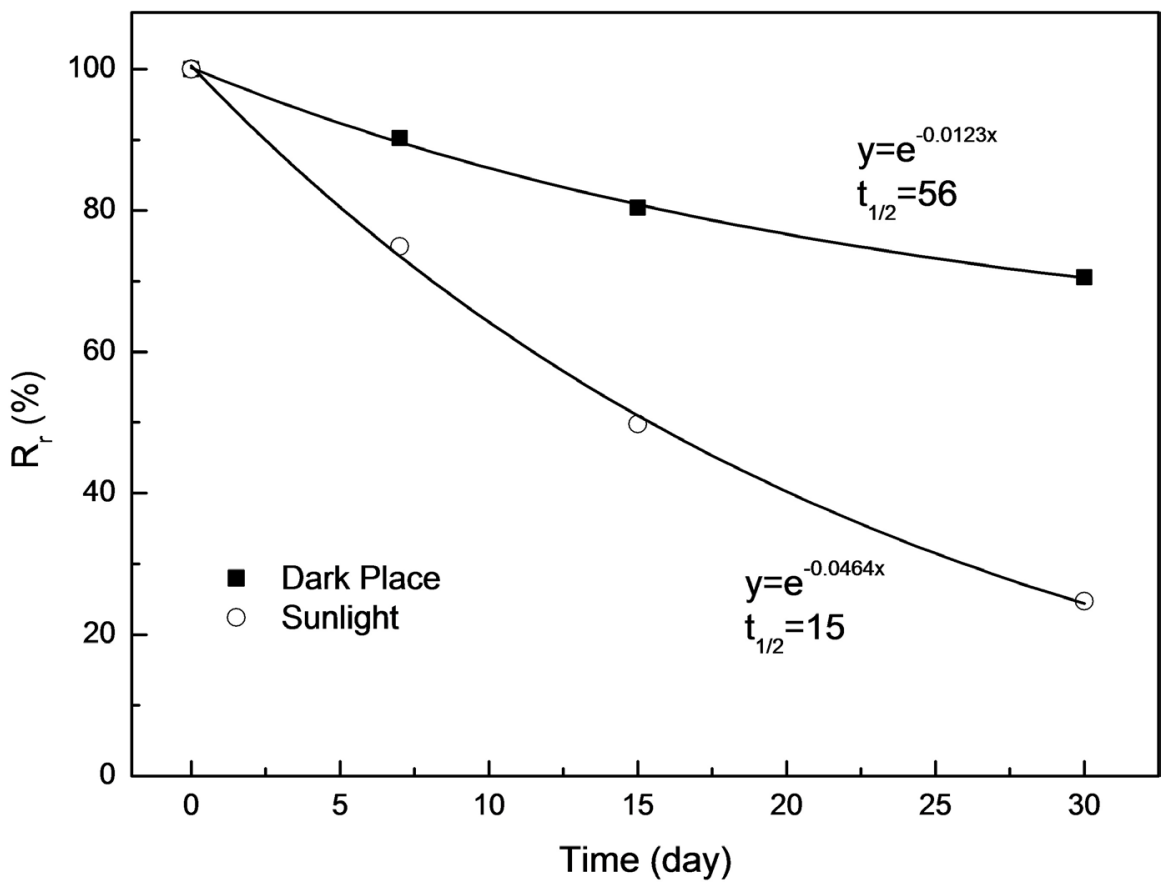

(a)

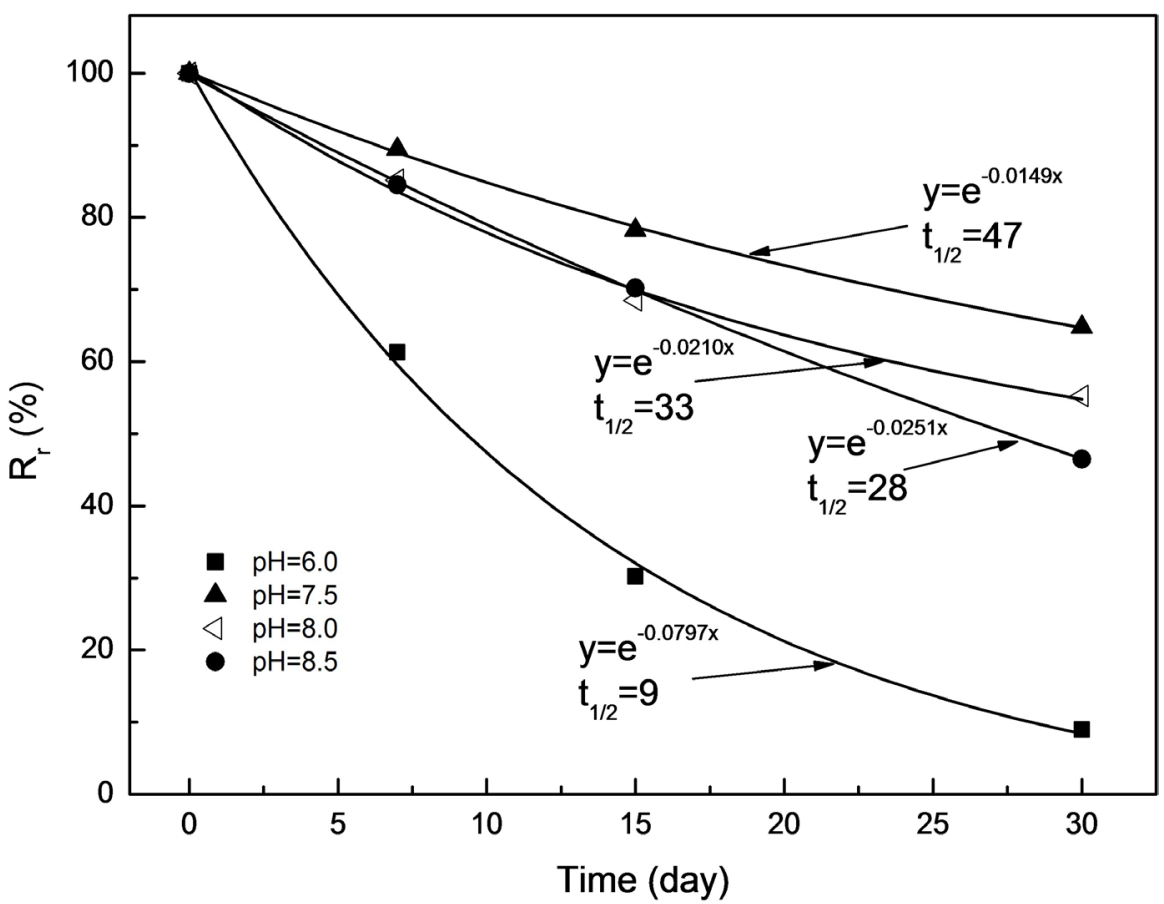

(b) 


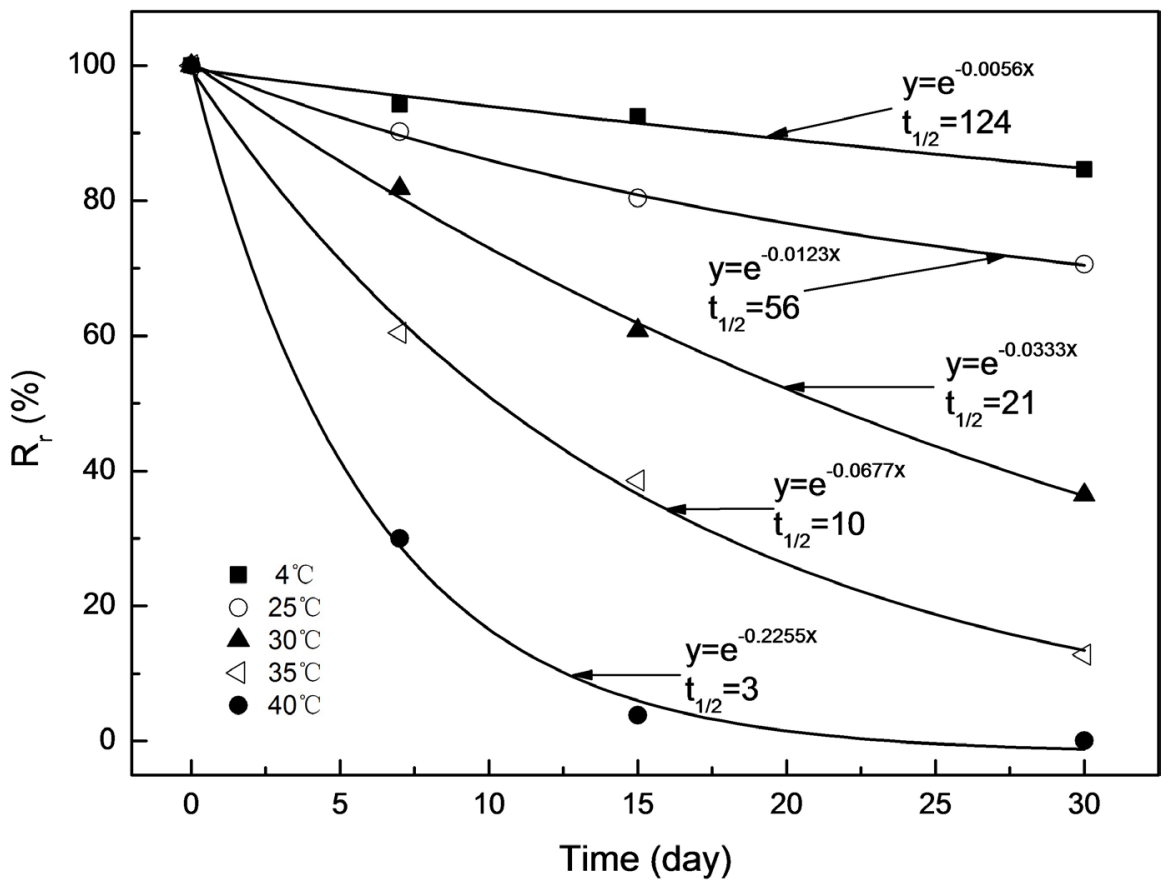

(c)

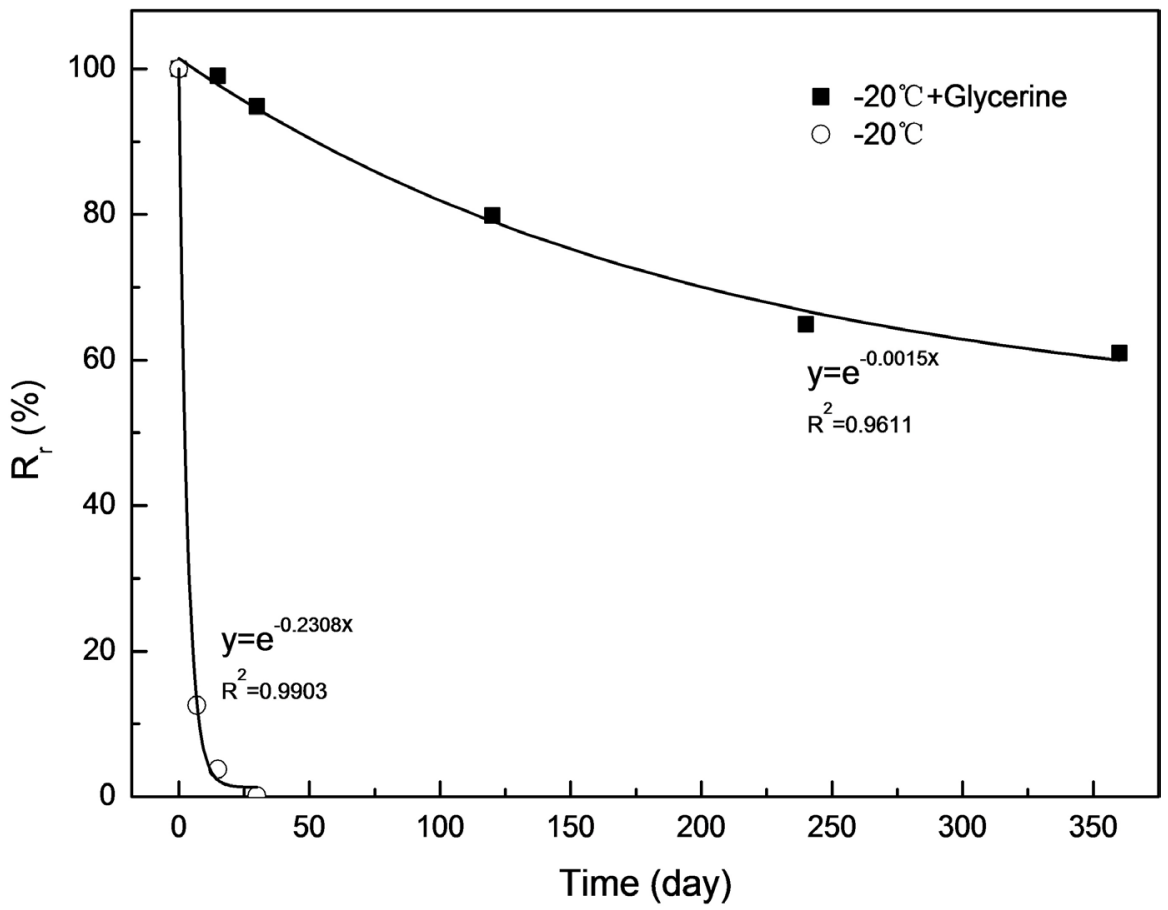

(d)

Figure 1. Factors of the preservation activity of nitrifying bacteria pellets. (a) Light; (b) $\mathrm{pH}$; (c) temperature; (d) freeze.

protective agent. The purpose of adding glycerin is to prevent extreme low temperature cause irreversible damage of nitrifying bacteria. As can be seen from Figure 1(d), the nitrification activity of nitrifying bacteria particles showed a decreasing trend with the freezing time. The activity of nitrifying bacteria par- 
ticles plummeted decay rate of $0.2308 \mathrm{day}^{-1}$, which is the highest value for all preservation conditions, while the shortest half-life of only 3 days under $-20^{\circ} \mathrm{C}$ low temperature without protective agent. This phenomenon confirmed that extreme cold conditions caused nitrifying bacteria cell lysis and death by freezing of intracellular water. Glycerol as a protective agent, the nitrifying bacteria particles decay rate of 0.0015 day $^{-1}$, half-life of up to 462 days, compared to $4^{\circ} \mathrm{C}$, reduce the decay rate of $1 / 4$, half-life of 3 times. Thus, adding glycerol as a protective agent, $-20^{\circ} \mathrm{C}$ cryopreservation of nitrifying bacteria pellets is suitable for long-term (1 - 2 years) storage.

\section{Discussion}

Table 1 summarizes the key results of preservation experiment. Through the impact analysis of the different preservation conditions including light, $\mathrm{pH}$, temperature and freeze on the polyurethane immobilized nitrifying bacteria pellets, the data of decay rate, fit factor and the half-life were listed in Table 1. Three appropriate means were acquired for nitrifying bacteria pellets preservation through the determination of the activities of nitrifying bacteria which had been preserved at different conditions. The first is dark at room temperature deionized water conservation method room temperature whose half-life of nitrifying activity is 56 days, which is suitable for nitrifying bacteria pellets' short term ( 1 - 2 months) preservation. The second is $4^{\circ} \mathrm{C}$ refrigeration dark deionized water conservation, whose half-life of nitrifying activity is 124 days, which is suitable for nitrifying bacteria pellets medium term (3- 6 months) preservation. And the third is a method by cryopreservation with glycerol at $-20^{\circ} \mathrm{C}$, whose

Table 1. Decay kinetic parameters of the nitrifying activity at different preservation conditions.

\begin{tabular}{|c|c|c|c|c|}
\hline \multicolumn{2}{|c|}{ Preservation conditions } & \multirow{2}{*}{$\begin{array}{c}\mathrm{K}_{\mathrm{m}}\left(\mathrm{day}^{-1}\right) \\
0.0464\end{array}$} & \multirow{2}{*}{$\begin{array}{c}\mathrm{R}^{2} \\
0.9988\end{array}$} & \multirow{2}{*}{$\frac{\mathrm{t}_{1 / 2} \text { (day) }}{15}$} \\
\hline & Sunlight & & & \\
\hline Hignt & Dark & 0.0123 & 0.9725 & 56 \\
\hline \multirow{4}{*}{$\mathrm{pH}$} & 6.0 & 0.0797 & 0.9985 & 9 \\
\hline & 7.5 & 0.0149 & 0.9937 & 47 \\
\hline & 8.0 & 0.0210 & 0.9728 & 33 \\
\hline & 8.5 & 0.0251 & 0.9978 & 28 \\
\hline \multirow{5}{*}{ Temperature } & 4 & 0.0056 & 0.9681 & 124 \\
\hline & 25 & 0.0123 & 0.9725 & 56 \\
\hline & 30 & 0.0333 & 0.9981 & 21 \\
\hline & 35 & 0.0677 & 0.9976 & 10 \\
\hline & 40 & 0.2255 & 0.9937 & 3 \\
\hline freeze & Glycerol & 0.0015 & 0.9611 & 462 \\
\hline$\left(-20^{\circ} \mathrm{C}\right)$ & - & 0.2308 & 0.9903 & 3 \\
\hline
\end{tabular}


half-life of nitrifying activity is 462 days, which is suitable for nitrifying bacteria pellets' long term ( 1 - 2 years) preservation.

\section{Conclusion}

The result showed that dark, deionized water and low temperature is suitable for polyurethane immobilized nitrifying bacteria pellets' long term preservation. Though this way, we can significantly reduce the decay index and prolong half-life of nitrifying bacteria pellets by changing conditions. The results also provided theoretical basis and implementation for nitrifying bacteria products' storage and transportation.

\section{Acknowledgements}

This project was sponsored by Shanghai Rising-Star Program (16QB1402200).

\section{References}

[1] Bae, W., Baek, S.C., Chung, J. and Lee, Y. (2002) Optimal Operational Factors for Nitrite Accumulation in Batch Reactors. Biodegradation, 12, 359-366. https://doi.org/10.1023/A:1014308229656

[2] Leenen, E., Dos Santos, V., Grolle, K., Tramper, J. and Wijffels, R.H. (2001) Characteristics of and Selection Criteria for Support Materials for Cell Immobilization in Wastewater Treatment. Water Research, 30, 2985-2996. https://doi.org/10.1016/S0043-1354(96)00209-6

[3] Jin, Y.W., Dong, Y.M. and Zhang, Z.J. (2012) Comparative Study of Conventional and Combined Process (Immobilized Microorganisms Pretreatment-Ultrafiltration) for Surface Water Treatment. Advanced Materials Research, 518-523, 2427-2430. https://doi.org/10.4028/www.scientific.net/AMR.518-523.2427

[4] Dong, Y.M., Zhang, Z.J., Jin, Y.W., Li, Z.R. and Lu, J. (2011) Nitrification Performance of Nitrifying Bacteria Immobilized in Waterborne Polyurethane at Low Ammonia Nitrogen Concentrations. Journal of Environmental Sciences, 23, 366-371. https://doi.org/10.1016/S1001-0742(10)60418-4

[5] Qiao, X., Zhang, Z., Chen, Q. and Chen, Y. (2008) Nitrification Characteristics of PEG Immobilized Activated Sludge at High Ammonia and COD Loading Rates. Desalination, 222, 340-347. https://doi.org/10.1016/j.desal.2007.01.150

[6] Dong, Y.M., Zhang, Z.J., Li, J., Wang, T. and Feng, Y.N. (2015) Removal of Ammonia Nitrogen Using Polyurethane hydrogel Immobilized Nitrifying Bacteria at Low Temperature. Chinese Journal of Environmental Engineering, 9, 3721-3726.

[7] Sumino, T., Nakamura, H., Mori, N., Kawaguchi, Y. and Tada, M. (1992) Immobilization of Nitrifying Bacteria in Porous Pellets of Urethane Gel for Removal of Ammonium Nitrogen from Waste-Water. Applied Microbiology and Biotechnolo$g y$, 36, 556-560. https://doi.org/10.1007/BF00170203

[8] Ren, J., Lin, W.T., Luo, X.C. and Xie, M.Q. (2007) Study on the Conservative Property and Degradation Kinetic of Nitrite Oxidizing Bacterial. China Biotechnology, 27, 61-65.

[9] Zhou, W., Kageyama, K., Li, F. and Yuasa, A. (2007) Monitoring of Microbiological Water Quality by Real-Time PCR. Environmental Technology, 28, 545-553. https://doi.org/10.1080/09593332808618814 
[10] Dong, Y.M., Zhang, Z.J. and Jin, Y.W. (2010) Synthesis and Application of Polyurethane Hydrogel Carrier on Nitrobacteria Immobilization. Advanced Materials Research, 152-153, 1533-1536.

https://doi.org/10.4028/www.scientific.net/AMR.152-153.1533

[11] Wijffels, R.H. and Tramper, J. (1995) Nitrification by Immobilized Cells. Enzyme and Microbial Technology, 17, 482-492. https://doi.org/10.1016/0141-0229(94)00099-D

[12] Groeneweg, J., Sellner, B. and Tappe, W. (1994) Ammonia Oxidation in Nitrosomonas at NH3 Concentrations near $k_{m}$ : Effects of $\mathrm{pH}$ and Temperature. Water Research, 28, 2561-2566. https://doi.org/10.1016/0043-1354(94)90074-4

[13] Villaverde, S., Garcia-Encina, P.A. and Fdz-Polanco, F. (1997) Influence of pH over Nitrifying Biofilm Activity in Submerged Boilers. Water Research, 31, 1180-1186. https://doi.org/10.1016/S0043-1354(96)00376-4

[14] Dong, Y.M., Zhang, Z.J., Jin, Y.W., Lu J., Cheng, X.H., Deng, Y.Y., Feng, Y.N. and Chen, D.N. (2012) Nitrification Characteristics of Nitrobacteria Immobilized in Waterborne Polyurethane in Wastewater of Corn-Based Ethanol Fuel Production. Journal of Environmental Sciences, 24, 999-1005. https://doi.org/10.1016/S1001-0742(11)60893-0

[15] Antoniou, P., Hamilton, J., Koopman, B., Jain, R., Holloway, B., Lyberatos, G. and Svoronos, S.A. (1990) Effect of Temperature and $\mathrm{pH}$ on the Effective Maximum Specific Growth Rate of Nitrifying Bacteria. Water Research, 24, 97-101. https://doi.org/10.1016/0043-1354(90)90070-M 